\title{
LMO2 Gene
}

National Cancer Institute

\section{Source}

National Cancer Institute. LMO2 Gene. NCI Thesaurus. Code C17973.

This gene plays a crucial role in hematopoietic development and is involved in transcriptional activation. 